\title{
Implementation of Kohort Mother Register By Coordinator Midwife of Public Health Center In District West Kotawaringin, Central Kalimantan
}

\section{Jatmiko Susilaningsih}

Master Program of Public Health, Institute of Health Sciences Strada Indonesia, Kediri

Email: michosusimj@gmail.com
Received : October 5, 2020

Accepted : November 30, 2020

Published : November 30, 2020

\begin{abstract}
The cohort register is an instrument for recording health services for pregnant women at the Public Health Center, which is a complete and continuous collection of all data. Each midwife provides services in the building and outside the building immediately takes notes. Compliance, consistency of midwives and the recording system of the Public Health Center greatly influenced the results of the data in the cohort register. A valid and reliable data source is a tool in the advocacy of policy makers in the progress of the program quickly and on target. The purpose of this study was to explore the implementation of the maternal cohort register by the midwife coordinating the Public Health Center. The research design used is descriptive qualitative. Data collection using in-depth interview techniques (depth interview) with semi-structured questions with a sample of 8 informants. The results showed that there was no Standard Operating Procedure for recording system services for pregnant women, resulting in no evaluation of service quality. The recording of $\mathrm{K} 1$ and $\mathrm{K} 4$ has been carried out. Revisits outside K1, K2, K3 and K4 and visits outside the region were not recorded in the cohort register. Data processing by grouping, tracing and validating data has not been maximal. Lack of understanding of the coordinating midwife, lack of supervision, training and evaluation from the Public Health Center and the Health Office are obstacles in the implementation of the mother cohort register by the coordinating midwife.
\end{abstract}

Keywords: Coordinator midwife, implementation, mother's cohort register

Copyright (C) 2020 IIK STRADA Indonesia All right reserved.

This is an open-acces article distributed under the terms of the Creative Commons Attribution-ShareAlike 4.0 International License.

\section{INTRODUCTION}

Public Health Center recording and reporting system is a vital instrument in the health information system. Information about morbidity, use of health services at Public Health Center, mortality and various other health information is useful for decision making and policy makers at the district or city or sub-district level (Anwar, 2009).

Effective data management (effective management of the data) is a characteristic that needs to be considered including the time to update files, the accuracy of data input, the maintenance of the unity of the data stored in the system. The need for data security that has been used, as well as adequate back-up facilities (Anwar, 2009).

Health services in the community are carried out through monitoring, controlling, and assessment activities which include recording, reporting, monitoring and evaluation. Recording and reporting are indicators of the success of an activity, without recording and reporting, any activities or 
programs that are carried out will not be visible. The output of recording and reporting is valuable and valuable information data when using appropriate and correct methods. So this data and information is the most important element in an organization, because it is the data and information that speaks of the success or development of the organization.

Various problems are still faced in the implementation of the health information system in Indonesia. These problems can be grouped into 3 problem groups, namely (1) weak governance, (2) frag of information systems, (3) weak data management and decision-making support systems (Permenkes 46, 2017).

Documentation is an important or valuable paper which is written or printed which functions or can be used as evidence or information. RI Minister of Health Decree No. 63 / Menkes // SK / II / 1981 one of the standard forms of recording is the KIA and KB registers. In Maternal and Child Health, the cohort register is a document evidence of the quality of maternal and child health services which temporarily describes the general state of maternal and child health, including risk factors and their development, target achievement of current goals and meeting indicators of minimum service standards coverage at Public Health Center.

The recording of the mother's cohort register is a complete cohort format, so the MCH status data can be observed and assessed accurately so that any problems can be detected as early as possible and can get a good subscription. (MOH, 2010)

In fact, in the Public Health Center and in the village, it is still found that recording and filling in the cohort register format is not in accordance with the existing guidelines, so that a lot of data is not recorded, and data needed is lost, even the presence of registration with the cohort register at the Public Health Center is seen as something that is quite a burden for the Public Health Center staff.

Through the results of a preliminary study on the implementation of the Mother cohort register by the Coordinator Midwife in West Kotawaringin Regency to program managers at the Provincial Health Office of Central Kalimantan and Kotawaringin Barat district offices, village midwives, and several Coordinator Midwife $s$ at the Public Health Center, obtained the following information:

1. Monev results from the MCH program manager at the provincial level to several Public Health Center in the district said that the mother cohort register was still an instrument for recording services The mother is both in the village and the Public Health Center, but there are still some coordinating midwives who have not filled in the cohort register according to the existing instructions.

2. The manager of the KIA program at the Kotawaringin Barat district office said that overlapping service data at KIA for Public Health Center in cities often occurs because the data source in the cohort register is incomplete.

3. Comprehensive $\mathrm{MCH}$ services were not documented in the mother cohort register, so it was not known whether the mothers had received maximum services.

4. Not all of the data collection of MCH services by village midwives was included or documented in the mother cohort register because the target of pregnant women was relatively few and the village environment was small so that information on maternal and child health was easy.

5. Data collection at the Public Health Center level which comes from various sources, namely polindes, Poskesdes, Pustu, private practice midwives, private practice doctors, is entered based on absolute numbers without being validated by the coordinating midwife.

6. Filling in the cohort register is not continuous and continuous, so that only individual data of pregnant women are obtained, without knowing and the overall picture.

7. The Coordinator Midwife said it was difficult and did not have time to enter the results of maternal and child health services in the register of each service provided because of the large number of registers currently used.

\section{MATERIALS AND METHODS}

This study used a qualitative research design with approach. This case studyintends to explore the implementation of a mother cohort register by the Coordinator Midwife of the Public Health Center in Kotawaringin Barat, Central Kalimantan. This research was conducted from 15 July to 25 August 2019 in Kotawaringin Barat Regency. Collecting data in this study using the interview method with semi-structured and in-depth questions. The tools used are in the form of field notebooks and cellphones which are then documented in the form of transcripts. In this study, data sources were 
obtained from research subjects consisting of 8 informants consisting of 8 main informants, coordinating midwives, 3 triangulation informants and Focus Group Discussion (FGD). Selection of informants using purposive sampling technique.

\section{RESULTS}

Kotawaringin Barat is one of the fourteen districts in West Kotawaringin. Kotawaringin Barat has its capital in Pangakalan Bun, located in the province of Central Kalimantan. The area of West Kotawaringin Regency is $10,759(\mathrm{~km} 2)$ with a population of 250,041 and a population density of 23.34. Administratively, Kotawaringin Barat Regency is divided into 6 sub-districts and 94 villages. Kotawaringin Barat (Kobar) is located between 3 districts, namely in the north bordering Lamandau Regency, in the east by Seruyan Regency, in the west bordering Sukamara Regency.

Table.1 Main informants

\begin{tabular}{llllll}
\hline NO & CODE & Age of & Education Last & $\begin{array}{l}\text { Length of time as } \\
\text { Coordinator } \\
\text { Midwife }\end{array}$ & Information \\
\hline 1 & S & 38 & D3 Midwifery & 3 years & Main informant \\
\hline 2 & SP & 38 & D3 Midwifery & 2 years & Main informant \\
\hline 3 & M & 38 & D3 Midwifery & 3 years & Main informant \\
\hline 4 & IS & 54 & D3 Midwifery & 5 years & Main informant \\
\hline 6 & N & 35 & D3 Midwifery & 3 years & Main informant \\
\hline 7 & R & 41 & D 3 Midwifery & 13 years & Main informant \\
\hline 8 & PS & 55 & D3 Midwifery & 5 years & Main informant \\
\hline
\end{tabular}

There are 3 triangulation information, namely (1) Kasi Kesga, Kotawaringin Barat Regency Office, (2) Staff of the Directorate of the Ministry of Health of the Republic of Indonesia Jakarta, (3) Coordinating Midwives at Public Health Center Koja, North Jakarta. To validate the data, an FGD was conducted with the coordinating midwives who were the main informants of 8 people, 2 midwives on duty at the Public Health Center and 2 coordinating midwives who were not the main informants.

Standard Operating Procedures for all Public Health Center were absent, but the Public Health Center had methods, stages and agreements in the recording process. Recording was not only the maternal cohort register but through several stages starting with declaration into the RM, then recorded in the $\mathrm{MCH}$ Handbook, recapitulated in the outpatient register and the mother cohort, and these answers were as expressed by the informants: $1,2,4,5,6,7$ and as follows:

"There is no SOP regarding the recording system with the mother cohort register, but there is an agreement among KIA officers, filling the cohort register is not straightforward but it is recorded in the register of pregnant women first according to the results of existing services, but we recorded it in the Medical Record, MCH book, outpatient register, then we recorded it in the cohort register" (Informants, 2,3,4,5,6, 8, I,)

The results of interviews from 8 informants found that all of Coordinator Midwife have understood $\mathrm{K} 1$ with the answers from all Coordinator Midwife, such as the informant's expression 1,2,3,4,5,6,7,8 as follows:

"The first visit of pregnant women (K1) was all pregnant women who visited for the first time or had first contact with health workers, they do not know the gestational age, "(Informant, 2, 3,4,5,6,7).

But the results of the interview also showed that there were visits by pregnant women from the Independent Practice Midwives (BPM), the data was recorded in the cohort register. After conducting tracing and ensuring that the pregnant woman is the target of the Public Health Center and entered as the target achievement of the Public Health Center, as informant 2 as follows stated by

"K1 from BPM or other health facilities, we confirm that it is our target for pregnant women at our Public Health Center, still enter it as an achievement for public health center and we record it in register kohor. ${ }^{(I n f o r m a n t 2)}$

The results of the study obtained a good understanding of $\mathrm{K} 4$ by stating the meaning of $\mathrm{K} 4$, it was revealed from the results of interviews with informants $1,2,3,4,5,6,7,8$ as follows 
"K4 visit was seen from the gestational age, visits in the third trimester, namely the gestational age of 37 - 42 weeks of 2 times "(Informant 1,2,3,4,5,6)

The focus of the fourth study was the result that revisits were visits from pregnant women who were not from $\mathrm{K} 1$ visits. $\mathrm{K} 2, \mathrm{~K} 3$, and $\mathrm{K} 4$ were not recorded in the cohort register but were recorded in the outpatient register, as the informant stated, 1,2,3,4,5,6,7,8 as follows:

"services for pregnant women who are not $K 1, K 2, K 3$ and $K 4$ were not recorded in the cohort

but recorded in the outpatient register "(Informants $1,2,3,4,5,6,7,8)$

The results of the interview revealed that pregnant women who were not targeted at the Public Health Center were not recorded in the cohort register, recorded in the RM, the outpatient register, as stated by informants 1, 2, 3, 4, 5, 6, 7, and 8 as follows: "no we recorded it in a cohort, but only recorded it in the outpatient register" (Informant 1,3,4,5,6,7,8)

The results of the study also revealed that data on pregnant women outside the region where there was no data processing at the Public Health Center, revealed as an expression. Informants as follows:

"Data outpatient registers outside the area, yes we don't process it, do we just record it, miss?" (Informant 3,5)

No cohort data processing, no tracing and data validation, recapitulation is done, namely only taking the number complete data K1, K4 and the number of deliveries without knowing the identity of the individual pregnant women. Data validation on overlapping data and various different data sources. Service standards, did not perform data processing to see the drop out of K1 or K4 visits revealed from informants, 1,2,4,5,6,7,8 as follows:

"The data processing in our cohort registers only takes the number of $K 1, K 4$, adding $K 1$ and

K4 from BPM and other private clinics, there is no name and service results " (Informants 1,2, 5) The

Use of cohort register data is very large including as a source of report data. PWS KIA every month, data sources to see K1, K4 coverage, number of deliveries, see the number of high-risk pregnant women, data on childbirth and postpartum and follow-up plans for the progress of the MCH program. like the informant's expression 1,2,3,4,5,6,7,8 as follows:

"For PWS KIA report data, the number of $k 1, K 4$, high risk detection, and reference data

sources during home visits if the target is not achieved," informants 2 " (Informants 1, 2,3,4

Research revealed that the implementation of the cohort register contained several obstacles in maximizing in terms of filling, data processing including from the health personnel itself is proven by the results of informant interviews $1,2,3,4,6,7$ as follows:

"The officer did not have time to record in the cohort register, the officer forgot to record it in the cohort register" ${ }^{\prime \prime}$ (nformant 8$)$

The results of this study also revealed that there was no supervision or training regarding the recording system with the mother cohort register from both district health offices and community health center leaders, as recently as 7 years ago. There was never any evaluation of data in the mother cohort register as the informant stated 2,3,5, 6,7,8 as follows:

"There is no supervision regarding the system for recording, processing and utilizing cohort register data" ${ }^{\prime \prime(\text { Informant 2,3). }}$

\section{DISCUSSION}

\section{Standard Operational Procedure}

The results of the study revealed that all Public Health Center did not have an SOP for recording health services for pregnant women with a maternal cohort register or a recording system in general, but each Public Health Center had methods or agreements such as recording starting with recording in RM as patient documents stored in the administration section., then recorded in the outpatient register as a monthly record of the number of patients who visited, recorded in the KIA book to be taken by the patient, and recorded in the cohort register as a result of a complete data source as the informant stated as follows: " There is no SOP regarding the registration system with a register mother cohort, but there is an agreement among KIA officers,

SOP is a document containing a series of instructions or rules regarding the process of activities for carrying out work tasks according to their functions. Maintain consistency of performance or certain conditions, as a rule in the implementation of recording work, reduce and minimize errors, in completing the work of officers in work because SOPs act as standardization. Contains work guidelines, historical documents, and provides procedures for the implementation of these activities or jobs. (Indah Puji, 2014) 
This condition is not in accordance with what it should be that the recording of the mother cohort register by Coordinator Midwife requires an SOP. The absence of these SOPs meant that the Public Health Center did not have a standard for assessing the quality of services and in the end the Public Health Center did not have documents that could explain and evaluate the implementation of the recording work process. Public Health Center do not have a valid and accurate data source document for pregnant women health services.

The SOP can be a Coordinator Midwife guide in the recording system even though the Public Health Center has already carried out stages in the recording process, but it is not used as a document in the form of an SOP that must be obeyed and implemented by all Coordinator Midwife s in doing so. The procedure or flow of recording at the Public Health Center through several stages or sequences has been carried out, how to do the recording, by whom the recording is, even though there is no written document that is open about the process. This resulted in not maximizing recording activities.

\section{The process of recording $\mathrm{K} 1$}

$\mathrm{K} 1$ is one of the various health indicators. $\mathrm{K} 1$ is a certainty that pregnant women wherever they are have received ANC services according to the expected standards. K1 shows that the management of the $\mathrm{MCH}$ program has been reached by pregnant women where the pregnant woman lives.

The results showed that all informants knew the meaning of K1. This can be seen from the explanation of $\mathrm{K} 1$ from the informant, what is $\mathrm{K} 1$, like the informant's expression as follows: "The first visit of pregnant women (K1) is all pregnant women who visit for the first time or have first contact with health personnel, do not know the age of pregnancy. "(Informant ${ }^{l)}$.

The duties and functions of the Coordinator Midwife are to provide guidance for the $\mathrm{MCH}$ program at the Public Health Center, the Coordinator Midwife assigned should have a very good understanding of the management of the $\mathrm{MCH}$ program. Management of the $\mathrm{MCH}$ program between K1 and K4 records into the cohort register. (Coordinator Midwife Guidelines, 2010).

$\mathrm{K} 1$ has been known to all Coordinator Midwife and is in accordance with the understanding that should be possessed by a Coordinator Midwife, to carry out the duties and functions in the MCH program development, especially recording cohort registers for K1. It is one of the indicators for the coverage of the MCH program, so understanding K1 is crucial in the successful achievement of the $\mathrm{MCH}$ program. The achievement of the K1 target shows that services for pregnant women in the area have been reached by every pregnant woman.

\section{The process of recording the $\mathrm{K} 4$ women}

The results of the study revealed that the Coordinator Midwife had known the meaning of K4 from the informants' answers as follows: visits of pregnant "Visits of pregnant women to the Public Health Center have been 4 times and 2 times in the 3rd trimester" (Informant5). In line with the interview with the informant, "K4 pregnant women are visited 4 times, two in the third trimester" (Informant7).

The duties and functions of the Coordinator Midwife are to provide guidance for the $\mathrm{MCH}$ program at the Public Health Center, the Coordinator Midwife assigned should have a very good understanding of the management of the $\mathrm{MCH}$ program. Management of the $\mathrm{MCH}$ program between K1 and K4 records into the cohort register. (Coordinator Midwife, 2010).

The understanding of K4 has been known to all Coordinator Midwife and is in accordance with the understanding that should be possessed by a Coordinator Midwife, to carry out the duties and functions in the $\mathrm{MCH}$ program development, especially recording cohort registers for $\mathrm{K} 4$. It is one of the indicators for the coverage of the $\mathrm{MCH}$ program, so understanding $\mathrm{K} 4$ is crucial in the successful achievement of the $\mathrm{MCH}$ program. The achievement of $\mathrm{K} 4$ shows that services for pregnant women in the area have been reached by every pregnant woman.

K4 visits to see that pregnant women have received quality, integrated and comprehensive services, it is hoped that the rights of every pregnant woman to receive quality Antenatal services are expected to be able to have a healthy and safe pregnancy. Can be addressed immediately if risk factors are found before delivery.

\section{Recording process for revisiting pregnant women who are not K1, K2, K3 and K4}

In the revisiting system the guidelines are not written, but based on the results of supervision from the provincial and district offices to the 2 research locations that the recording in the cohort 
register is only for $\mathrm{K} 1, \mathrm{~K} 2, \mathrm{~K} 3$ and $\mathrm{K} 4$, and for return visits recorded in the outpatient register, according to the informant as follows: "The cohort register is only for $K 1, K 2, K 3$ and $K 4$, according to the direction of the office, the return visit is recorded in the outpatient register only." (Informant 5). This is reinforced by the statement of triangulation 1 " if the cohort register is only for K1, K2, K3 and K4 if the return visits are recorded in the outpatient register" (triangulation informant 1).

However, it is inconsistent with the results of the 2 and 3 triangulation interviews that all the results of examinations of pregnant women should be recorded in the cohort register as follows: "Everything should be recorded in the cohort register, all examinations of pregnant women" (triangulation informant 2) and this was also confirmed by triangulation 3 informants are as follows: "the results of $K 1, K 2, K 3$ and $K 4$ examinations and return visits are all recorded in the cohort registry" (triangulation 3)

The results of observations show that data in the cohort register are only $\mathrm{K} 1, \mathrm{~K} 2, \mathrm{~K} 3$ and $\mathrm{K} 4$, for subsequent visits it is recorded in the outpatient register only, so that the data in the cohort register did not show a picture of the overall health of pregnant women. Every pregnancy, in its development, has the risk of experiencing complications or complications. Therefore, antenatal care must be routine and registered in one register to make it easier to see the overall condition of pregnant women from the beginning of pregnancy to delivery.

To obtain data on the health of pregnant women continuously, it will be easier to record the results of examinations for pregnant women in one data source. The cohort register is a complete data source and is the result of data recapitulation of pregnant women. Researchers have not found any record keeping guidelines about this.

\section{Recording of visits outside the Public Health Center area}

Some of the research locations are densely populated and there are relatively many health facilities, making it easier for pregnant women to have access to prenatal examinations according to the wishes of the patient himself without boundaries. Public Health Center has a target area, with predetermined targets for pregnant women and boundaries which are the responsibility of all health program activities, including the $\mathrm{MCH}$ program.

The results of the study revealed that pregnant women who conducted examinations at other Public Health Center, service data were recorded in the outpatient register as the informant said as follows: "For pregnant women, we are not our target, we just record it in the outpatient register, sis" (informant2), as well as the expression. Informant 5 is as follows "for data on pregnant women who are outside our area, we only record it in the auxiliary book or outpatient register book" (informant 5). Public Health Center have responsibilities according to targets that have been determined by the concept of a region. Public Health Center is responsible for providing services for pregnant women, recording and reporting. Public Health Center have limits and targets according to the targets that have been determined since the beginning of the year. All Public Health Center are obliged to provide services to the community from anywhere in accordance with existing standards.

The standard working area for the Public Health Center is one sub-district. However, if there is more than one health center in one sub-district, the responsibility for the work area is divided between the health centers, taking into account the integrity of the concept of the area and the target, the program targets that have been determined from the local health office, each Public Health Center is operationally responsible to the district health office (Coordinator Midwife, Depkes 2010).

Examination of pregnant women can be anywhere and anytime, with the various kinds of health facilities available, pregnant women can carry out examinations according to the pregnant woman's choice. The territorial system in BPJS membership makes it easy for pregnant women to conduct examinations at health facilities or BPM even though it is not the area where the examination should be. BPJS clamps for ANC examinations and delivery can be carried out by BPM or health facilities that have collaborated with BPJS without knowing the concept of area, this really gives pregnant women the opportunity to carry out examinations at health facilities and BPM according to their choices.

\section{Data processing register cohort Mother}

The study also reveals that not all Coordinator Midwife perform data processing to the maximum, the source data from a wide variety of not being material recaps service data mom, is not done checking, the suitability of such data as the phrase following informant: "we just taken the data on the number K1, K4 only "(Informant 1). 
From the results of observations by comparing the PWS KIA report data sent to the district office with the number of K1 in the cohort register in June 2019, the number of K1 in the cohort register in June 2019 was different.

Most of the Public Health Center did not perform data management optimally. Public Health Center only processed the number of $\mathrm{K} 1, \mathrm{~K} 4$ and childbirths without conducting tracing, grouping data. There is a high probability that data on pregnant women will overlap. This shows that the management of the maternal cohort register data tends to be oriented only to the number data on the indicators used for the evaluation of the $\mathrm{MCH}$ program, without giving great attention to the

\section{The utilization of the Mother's Cohort Register data.}

Utilization of the cohort register data is the data source for the PWS KIA report preparation and the program data source. Other.

Barriers to implementing the cohort register began with the staff lacking consequences in recording, forgetting, not having time and a lack of understanding of the midwife in the recording system through the mother cohort.

The results of this study also revealed that there was no supervision or training regarding the recording system with the mother cohort register from both district health offices and community health center leaders, most recently 7 years ago. There has never been any evaluation of data in the mother cohort register as the informants 2,3,5,6,7,8 stated as follows: "There is no supervision of the system for recording, processing and utilizing cohort register data" (Informant 2,3)

In line with the results Yudhy Daramawan et al. (2015) found that good data quality comes more from good supervision, while poor data quality comes from poor supervision. Supervision and evaluation of cohort register data from Public Health Center leaders is useful to see together what are the weaknesses and strengths of past, present and possible activities so as to get better results in the future, create a climate of cooperation and mutual cooperation, influencing the $\mathrm{MCH}$ program, maintaining quality, namely the role of the chairman of the leadership, cooperation, leadership attention, cooperation with facilitators and the amount of leadership supervision.

This proves that Coordinator Midwife still needs supervision from the leadership or the health office to encourage, direct and provide knowledge and skills in implementing the cohort register at the Public Health Center.

\section{CONCLUSION}

Recording of service results is not supported by the existence of an SOP for the cohort registration system, resulting in poorly documented ANC services at the health center.

The system for recording K1 and K4 into the cohort register was not in accordance with the guidelines even though all Coordinator Midwife s had understood the meaning of K1 and K4. This shows that there are obstacles in applying Coordinator Midwife 's knowledge to K1 and K4 in applying the registration of the mother cohort register at the Public Health Center.

The standard of return visit service is to use the ANC $10 \mathrm{~T}$ standard and visits of pregnant women outside the health center area are not recorded in the cohort register and data processing is not carried out so that the pregnant woman does not have data to be used as the basis for further services. Most Public Health Center only manage the number of K1 and K4 without doing data validation.

\section{ACKNOWLEDGMENTS}

The author would like to thank all of participants of this study.

\section{CONFLICTS OF INTEREST}

The author declares that they have no conflict of interest

\section{REFERENCES}

Arikunto, S.(2013) Prosedur Penelitian: Suatu Pendekatan Praktik, Jakarta: Rineka Cipta

Anwar Saiful. (2016). Analisis, Preancangan dan Evaluasi Sistem informasi Kesehatan. Jakarta: Glora Madani Pres

Bungin, B. (2014). Penelitian Kualitatif. Edisi kedua. Jakarta: Kencana Pranemedia Group.

Dessler, Gary. (2015). Manajemen Sumber Daya Manusia. Edisi Kesepuluh. Jakarta Barat. PT Indeks. 
Dinas Kesehatan Kabupaten Kotawaringin Barat. (2018). Profil Kesehatan Tahun Kabupaten tahun 2017.Kotawaringin Barat: Dinkes Kotawaringin Barat

Dunn, William N. (2017). Pengantar Analisis Kebijakan Publik. Yogyakarta : Gajah Mada University Press

Dwidjowijoto, Riant Nugroho. (2014). Kebijakan Publik: Formulasi, Implementasi, dan Evaluas., Jakarta : PT. Elex Media Komputindo

Herdiansyah, Haris. (2010). Metodologi Penelitian Kualitatif untuk Ilmu-Ilmu Sosial. Jakarta: Salemba Humanika.

Husaini Usman. (2011). Manajemen; Teori, Praktik dan Riset Pendidika. Jakarta: Bumi Aksara.

HIvancevich, John, M, dkk. (2009). Perilaku dan Manajemen Organisasi, edesi 7 jilid 2 dan 2. Jakarta : Erlangga.

Isti,aroh dkk. (2018). Studi pencatatan dan pemanfaatan kohort KIA di kabupaten Pekalongan

Indah Puji Hartatik. (2014). Praktismengembangkan SDM: Jakarta Flash Books, 2014

Kementerian Kesehatan. (2016).Keputusan Menteri Kesehatan Nomor 43 /Menkes/IX /2016 Standar Pelayanan Minimal bidang Kesehatan. Jakarta Kementerian Kesehetan Republik Indonesia

Mangkunegara, Anwar Prabu. (2015). Evaluasi Kinerja SDM. Bandung : Refika Aditama.

Mathis R.L dan Jackson J.H. (2012). Manajemen Sumber Daya Manusia. Jakarta: Salemba Empat.

M. Taufiq Amir. (2014). Manajemen Strategik; Konsep dan Aplikasi. Jakarta: Penerbit Rajawali Press

Focus Graoup Discussion (Diskusi Kelompok Terarah): ((http:www.markettrends.asia/2013/02/fokus group-discussion-reserrch) diakses 10 maret 2019

Moleong, Lexy J. (2014). Metodologi Penelitian Kualitatif. Bandung: PT Remaja Rosdakarys.

Notoatmodjo. (2015). Metodologi Penelitian Kesehatan. Jakarta: Rineka Cipta

Nugroho, Riant. (2012). Public Policy. Jakarta: PT. Elex Media Komputindo

Saryono. (2014). Metodologi PenelitiaKualitatif dalam Bidang Kesehatan. Yogyakarta: Nuha Medika.

Saryono dan Anggraeni, Mekar Dwi. (2013). Metodologi Penelitian Kualitatif dan Kuantitatif dalam Bidang Kesehatan. Yogyakarta: Nuha Medika.

Sugiyono. (2017). Metode Penelitian Kebijakan: Pendekatan Kuantitatif, Kualitatif, Kombinasi, R\&D dan Penelitian Evaluasi dan R\&D. Bandung: Alfabeta. 